\title{
Discarded Cathode Ray Tube Glass as an Alternative for Aggregate in a Metakaolin-Based Geopolymer
}

\author{
Natalia Wielgus (D), Marcin Górski *(D) and Jan Kubica (D) \\ Department of Structural Engineering, Faculty of Civil Engineering, Silesian University of Technology, \\ Akademicka 5, 44-100 Gliwice, Poland; natalia.paszek@polsl.pl (N.W.); jan.kubica@polsl.pl (J.K.) \\ * Correspondence: marcin.gorski@polsl.pl
}

\begin{abstract}
Cathode Ray Tube (CRT) glass belongs to the group of wastes which are hard to be recycled due to their toxic metals content. Geopolymers are relatively new environmentally friendly materials which allow for the use of different types of wastes within their matrix. The following paper combines both issues and presents a new geopolymer mixture containing discarded CRT glass as a replacement for an aggregate. The main goal of the paper is to describe the basic mechanical behavior of the new type of metakaolin-based geopolymer and to discuss different factors influencing it. After the preliminary research, the mixture containing $50 \%$ of CRT glass was chosen for further tests. However, according to results, CRT glass content has no evident influence on flexural or compressive strength. Summarizing the second part of the research, it was decided that the following parameters are optimal from the mechanical, economic and environmental points of view: metakaolin to CRT glass ratio 1:1 (by mass), CRT glass of size up to $4 \mathrm{~mm}$, curing at the room temperature, sodium hydroxide concentration $10 \mathrm{~mol} / \mathrm{L}$. According to the authors, the presented geopolymer is a promising building material. Further tests shall be done to describe new material more precisely.
\end{abstract}

Keywords: CRT glass; geopolymer; curing temperature; aggregate size; $\mathrm{NaOH}$ molarity; compressive and flexural strength

Citation: Wielgus, N.; Górski, M.; Kubica, J. Discarded Cathode Ray Tube Glass as an Alternative for Aggregate in a Metakaolin-Based Geopolymer. Sustainability 2021, 13, 479. https://doi.org/10.3390/su 13020479

Received: 26 November 2020 Accepted: 31 December 2020 Published: 6 January 2021

Publisher's Note: MDPI stays neutral with regard to jurisdictional clai$\mathrm{ms}$ in published maps and institutional affiliations.

Copyright: (C) 2021 by the authors. Licensee MDPI, Basel, Switzerland. This article is an open access article distributed under the terms and conditions of the Creative Commons Attribution (CC BY) license (https:// creativecommons.org/licenses/by/ $4.0 /)$.

\section{Introduction}

Cathode Ray Tube (CRT) glass is a basic constituent of all old television sets and computer screens. It can be classified into three types of glass: panel, funnel and neck glass. While the panel glass is relatively safe, the funnel and neck parts contain a high level of lead which is categorized as hazardous for human health and the environment [1]. Once being an essential component of the only available type of screen, CRT glass is becoming displaced now by newer technologies such as plasma display panel (PDP), liquid crystal display (LCD) or light-emitting diode (LED) [2]. As a result, more and more CRT glass has become a hazardous waste material which is problematic and challenging both for disposing on landfills as well as for recycling [1]. Unquestionably, the recycling of wastes is more promising for humanity than disposing of wastes, and that is the reason a lot of attention is paid nowadays to the topic of recycling. Qi et al. (2019) [2] indicates two basic possibilities of CRT glass recycling: (1) in closed-loop which is simply the creation of new CRT glass from the old one, and (2) in open-loop which involves the use of CRT glass during the production of another material. The first possibility is more effective but shortsighted, so finally, the scientists have placed their hopes in open-loop recycling of CRT glass. The great potential in that field lies in various construction and building materials: foam glass-ceramic, glass tiles, ceramic glazes, cement mortar and paste, concrete or cement and clay bricks [3]. The new chapter in the use of CRT glass in the construction industry can be connected with geopolymers and supplement studies which have been conducted so far on the topic.

According to Joseph Davidovits (who is claimed to be a father of term "geopolymer" and a pioneer in work on this material) "geopolymers are ceramic-like inorganic polymers 
( ... ) consisting of chains or networks of mineral molecules linked with covalent bonds" [4]. They are built of raw materials (mostly alumino-silicates in the form of powders) chemically activated by alkaline, liquid medium (or in rare cases by acidic medium). According to Davidovits, geopolymers can be considered both as a new material, new type of binder and a new cement [4]. Geopolymers allow for the reduction of greenhouse gas emission [5], enable reusing of common industrial waste such as volcanic and fly ash or slag in the form of secondary input [6] and also allow use of a variety of less common wastes such as silicon carbide sludge [7]. Geopolymers also allow for the next possibility of use of CRT glass, especially since geopolymers are claimed to have excellent properties for immobilization of hazardous elements [8]. The immobilization process involves both the physical encapsulation and the chemical bond, which is created by the adsorption of the heavy metal ions within the geopolymer structure [8]. However, not all metals can be immobilized in an equal ratio. Palomo et al. (2003) [9] reports problems with stabilization of chromium. Though, the same geopolymer matrix can be successfully used for solidifying lead. Ji et al. (2020) [10] derives high efficiency in immobilization of Cd, Zn and $\mathrm{Pb}$ by metakaolin-based geopolymer. Professors Deja and Małolepszy reported high immobilization of $\mathrm{Zn}, \mathrm{Cd}, \mathrm{Pb}$ and $\mathrm{Cr}$ elements inside alkali-activated cementitious slag materials $[11,12]$. The properties of heavy metals immobilization are particularly desired when it comes for the application of CRT glass in geopolymers.

\subsection{CRT Glass in a Concrete}

The issue of the use of CRT glass in concrete was widely raised in the past. Since the application of CRT glass in concrete is the most related and may be the most similar to the application of CRT glass in geopolymers, authors decided to present this topic within the framework of the introduction. The majority of scientific papers report attempts of the use of CRT glass in the form of fine aggregate [13-20] although there are also some examples of using of powdered CRT glass as a partial replacement of the cement [21]. The vast majority of scientists conclude that incorporation of CRT glass into the concrete mixture is a promising direction for the recycling of that hazardous material; however, one should be aware of the possible negative influence on compressive, flexural and tensile splitting strength $[14,15,17,19,20,22,23]$. The weaker interfacial transition zone between CRT glass particles and concrete than between sand and concrete results in weak bonding, and is one of the explanations for worse mechanical behavior [18,22]. By contrast, some scientists indicate a possible positive influence of CRT glass on concrete strength $[13,16,21]$. Additionally, there are reportedly some other advantages of using CRT glass instead of the part of the common aggregate such as reduced segregation, bleeding and drying shrinkage [19] or enhanced resistance to chloride ion penetration [15]. What is more, studies have shown that CRT glass possesses good shielding properties which makes it potentially good for radiation shielding applications [24]. Ling et al. (2012) derived that a partial replacement of river sand with CRT glass in the cement mortar increases its shielding properties by having an atomic structure which adversely interacts with the X-radiation and reduces its depth of penetration. Only $\sim 40 \%$ of the material is needed to limit the dose rate by one-half while using CRT glass instead of sand in radiation shielding concrete wall [22,23]. Liu et al. (2019) [14] claims that CRT glass can be as well used as a partial replacement of high-density magnetite sand in radiation shielding concrete. Due to the hazardous character of the CRT glass, the important part of research is to establish if incorporation of that material into the concrete is safe for the environment. Wei et al. (2020) [18] and Liu et al. (2020) [20] report that the lead leaching measured during the tests fulfilled restriction limits. Pauzi et al. (2019) [17] also reports fulfilment of the limits, although he stresses that the smaller the size of CRT glass the more leaching of lead is observed. Then, Romero et al. (2013) [13] presents the solution in the form of incorporation of biopolymer into the structure to meet all environmental standards. 


\subsection{Utilisation of Glass in Geopolymers}

The addition of powdered conventional waste glass into the geopolymer matrix is widely reported in the literature [25]. Aside from the ecological benefits, incorporation of waste glass can also improve some parameters of the mixture or hardened material. Si et al. (2020) [26] reports that addition of glass powder increases the workability of the metakaolin-based geopolymer mixture, elongates initial and final setting time, reduces shrinkage, densifies the structure and refines the pores of the synthesized binder. Small quantities of glass powder (up to $10 \%$ ) enhance the compressive strength, although, the high ratio of glass powder can reduce the geopolymeric gel formation and decrease the compressive strength $[26,27]$.

Zhang et al. (2020) [28] found out that the addition of a milled glass of proper particle size from waste bottles enhances the compressive strength of ground granulated blast furnace slag-based geopolymer and fly ash-based geopolymer. The degree of geopolymerization, and simultaneously the compressive strength, increases with the decrease of glass particle size. The best results were obtained for the mean diameter of glass equal to $49.0 \mu \mathrm{m}\left(\mathrm{D}_{50}=41.9 \mu \mathrm{m}\right)$. On the 28th day slag-based geopolymer compressive strength was increased by $\sim 18 \%$ and $\sim 144 \%$ (for samples cured at $50{ }^{\circ} \mathrm{C}$ and $80^{\circ} \mathrm{C}$ respectively) after addition of waste glass. The 28th day fly ash-based geopolymer cured at $80^{\circ} \mathrm{C}$ was increased even by $\sim 190 \%$ after addition of waste glass. Scientists report the possibility of the activation of pure glass waste as well. However, the geopolymerization occurs only at high curing temperatures (over $80^{\circ} \mathrm{C}$ ), and even then compressive strength of hardened material does not exceed $15 \mathrm{MPa}$. Vafaei et al. (2016) [29] obtained pure waste glass-based geopolymer of compressive strength only about $10 \mathrm{MPa}$ cured at $95{ }^{\circ} \mathrm{C}$. On the other hand, the glass waste-based geopolymer with the little (8-24 wt.\%) addition of calcium aluminate cement achieves high compressive strength (nearly $90 \mathrm{MPa}$ ). By contrast, Idir et al. (2020) [30] developed waste glass-based geopolymer with the sand aggregate of flexural strength around $7 \mathrm{MPa}$ and compressive strength up to $50 \mathrm{MPa}$. Three different types of glass were examined: flat, hollow and windshield glass. Geopolymer was cured at $60^{\circ} \mathrm{C}$. Chen et al. (2016) [31] reports even higher compressive strength of waste glass-based geopolymer, up to almost $140 \mathrm{MPa}$. Xiao et al. [32] tried to activate geopolymer based on pure waste glass at ambient temperature, but, the material could barely reach $5 \mathrm{MPa}$ after 60 days of curing. Notwithstanding, scientists concluded that glass waste could partially replace fly ash as a raw material. Aside from the geopolymers based on conventional raw materials, previous studies also cover the addition of powdered waste glass to geopolymer based on red mud [33], tungsten mining waste mud [34], low purity metakaolin [35] or marble sludge [36].

Waste glass can be recycled in geopolymer not only as a replacement of raw material. Some scientists devote their work to examining usability of waste glass fibers as a reinforcement in geopolymer matrix [37]. Senff et al. (2020) [38] reports reinforcing fly ash-based geopolymer foams with the use of glass fiber waste being the byproduct of wind turbine blade production. Geopolymer foam modified with glass fibers shows increased strength (both flexural-up to $23 \%$ and compressive - up to 30\%) without the significant change of thermal conductivity. Bai et al. 2020 [39] presents using glass fibers for enhancement flexural and compressive strength of metakaolin-based geopolymer foams.

Waste glass can be used as an alternative for fine sand in a geopolymer matrix as well. The presence of glass aggregate increases alkalinity what results in a higher extent of dissolution and reaction, leading to a compact and robust matrix [40]. Khan et al. (2020) [41] observed that both short-term and long-term compressive strength declines monotonically with the increase of the glass content but the difference is vanishing in time. On the 7th days and 90th days compressive strength of samples containing only glass is respectively $\sim 12 \%$ and $\sim 5 \%$ smaller than the strength of samples containing the sand only. Besides, the replacement of sand with waste glass in fly ash and slag-based geopolymer leads to an increase of void volume and the reduction of drying shrinkage and of chloride permeability [41]. 
Except for conventional waste glass (coming mostly from old glass bottles), some research focuses on glass wastes coming from other sources such as thin-film transistorliquid display waste glass [42] or discarded fluorescent lamps [43].

The topic of the utilization of CRT glass in geopolymers was also previously explored; however, the number of papers is limited, and they focus mainly on powdered CRT glass as a replacement of raw material. This topic was raised several times by Romanian scientists [44-46]. The main goal of these researches was to assess the possibility of use of powdered CRT glass of high lead content ( $>15 \%$ ) from discarded television sets and computer screens in geopolymer. The mixture was composed of two kinds of a raw material (fly ash or granulated blast furnace slag), sodium silicate, sodium hydroxide and powdered CRT glass which was dosed such to obtain $2-10 \%$ of $\mathrm{Pb}$ in the mixture. Tests have shown that early compressive strength is affected negatively by the addition of CRT glass; however, long term compressive strength is not influenced or can be even enhanced. The replacement of the active binding component with CRT glass decreases the hardening rate. Examination of slag-based geopolymer proves that the hydration process is not affected by small amounts of $\mathrm{Pb}$, but high $\mathrm{Pb}$ content retards hydration even under the initial heat treatment conditions. Lead leaching test revealed a very high degree of $\mathrm{Pb}$ immobilization (>98\%). According to Romanian investigations, the cumulative lead released during the leaching test is below the emission limit and the presented geopolymer with CRT glass can be used as a building material without environmental restriction [44-46]. Catauro et al. (2017) [47] presents research done on geopolymer with partial replacement (40\%) of metakaolin with two types of powdered CRT glass rich in $\mathrm{Ba}$ and $\mathrm{Sr}$ or $\mathrm{Pb}$. According to authors, CRT glass can be considered as a filler which is not highly reactive but does not retard the geopolymerization process. Leaching of heavy metals is reduced in comparison to the pure CRT glass but still exceeds the limits. Ogundiran et al. (2018) [48] reports a similar experiment. Metakaolin clay was replaced with powdered CRT glass of high $\mathrm{PbO}$ content $(24 \%)$. Scientists noted the following consequences of the increase of CRT glass content: elongation of the setting time, growth of flexural and compressive strength (both early and late), decrease of the water absorption, increase of workability of fresh mixture and increase of the density of the hardened material. Geopolymer containing 20\% CRT glass (which was the highest tested replacement rate) still fulfilled leaching limits. Authors concluded that considering these particular parameters, metakaolin-based geopolymer with CRT glass can be used as a building material. Long et al. (2019) [49] reports substituting ground granulated blast furnace slag with powdered CRT glass in alkali-activated slag mortars. CRT glass shows relatively high pozzolanic activity, however, not as high as slag reactivity which influences negatively flexural and compressive strength of hardened material. On the other hand, CRT glass mitigates the ASR expansion of a geopolymer mortar (ASR - alkali-silica reaction-deleterious chemical reaction leading to the internal stresses and cracking; ASR can take place in geopolymer between alkali activator and aggregate [50]). Addition of glass has no significant effect on types of geopolymerization products but with the increase of its content, the ability of solidification of heavy metals of the matrix decreases. Authors conclude that considering the environmental issues, the substitution rate of CRT glass should not exceed 50\%. A thorough investigation of the ability of encapsulation of toxic heavy metals from CRT glass within metakaolin-based geopolymer has been done recently by Carrillo et al. (2021) [51]. Scientists observed that an immobilization process is more effective when $\mathrm{Si}$ and $\mathrm{Al}$ particles from the CRT glass grains are dissolute, which is promoted in low alkaline conditions. For the immobilization of heavy metals, the reaction between dissolved particles from glass and the raw material is needed. Thanks to the high dissolution of Si and Al from CRT glass powder, the toxic metals are anchored and encapsulated in the new crystalline phase, albite. According to the researchers, if the proper alkaline conditions are assured, even the maximum tested amount of CRT glass (which was $20 \%$ with respect to the weight of metakaolin) can be used in metakaolin-based geopolymer and still fulfill the leaching regulatory limits for $\mathrm{Pb}$ and $\mathrm{Ba}$. 
While the number of papers devoted to CRT glass recycled in geopolymer is not impressive, there is barely any information available on replacement of aggregate with crushed CRT glass particles. The only research the authors of the paper could find was derived by Czech scientists [52,53]. The experiment involved the addition of crushed glass from cone and screen parts of discarded cathode ray tubes (with high $\mathrm{Pb}$ content) into the metakaolin or slag-based geopolymer matrix. Particles smaller than $63 \mu \mathrm{m}$ were treated as a raw material while particles ranging between $63 \mu \mathrm{m}$ and $5 \mathrm{~mm}$ played the role of a fine aggregate. The compressive strength results of hardened material ranged from 11.2-119.2 MPa in relation on mixture composition (the type of raw material, size of CRT glass particles, binder/activator ratio, metakaolin/CRT glass ratio). The reaction between the surface of the glass grains and geopolymer matrix was observed. Despite high strength, the results of leaching tests were not optimistic. According to the work [52], geopolymer with CRT glass in the form of the aggregate does not fulfill requirements for wastes which can be stored on landfills without any special treatment. The flexural strength was not examined during the research process.

The only extent publication (found by the authors) raising an issue of CRT glass replacing aggregate in metakaolin-based geopolymer [52] does not cover all possible aspects of that topic. Scientists do not mention flexural strength and report that compressive strength tests were partly done on samples of irregular shape. Besides, samples were cured only at the room temperature. In summary, the state of the art analysis proved that issue of CRT glass replacing aggregate in metakaolin-based geopolymer is not examined sufficiently in the literature, especially in the range mechanical properties of such geopolymeric materials. The main goal of the current paper is to enrich existing knowledge about use of crushed CRT glass within the geopolymer matrix, thus providing another possibility for recycling of this hazardous material.

\section{Materials and Methods}

\subsection{Materials}

The mixtures were composed of raw material-metakaolin, aggregate-crushed CRT glass and activators-water solutions of sodium hydroxide and sodium silicate.

The metakaolin (Astra MK 40) was obtained directly from the producer ASTRA Technologia Betonu ${ }^{\circledR}$. Metakaolin was not subjected to any additional pretreatment after receiving from the producer. The exact composition is given in Table 1 . The particle size distribution of the metakaolin as well as the finest particles of CRT glass, presented in Figure 1, was done with the use of the laser particle analyzer.

Table 1. Chemical composition of metakaolin [\%] ${ }^{1}$.

\begin{tabular}{lllllllllllll}
\hline $\mathrm{SiO}_{2}$ & $\mathrm{Al}_{2} \mathrm{O}_{3}$ & $\mathrm{~K}_{\mathbf{2}} \mathrm{O}$ & $\mathrm{TiO}_{2}$ & $\mathrm{Fe}_{\mathbf{2}} \mathrm{O}_{3}$ & $\mathrm{CaO}$ & $\mathbf{M g O}$ & $\mathbf{H}_{\mathbf{2}} \mathbf{O}^{-}$ & $\mathrm{Na}_{\mathbf{2}} \mathbf{O}$ & $\mathbf{P}_{2} \mathrm{O}_{5}$ & $\mathrm{Cl}$ & $\mathbf{M n O}$ & $\mathbf{S}$ \\
\hline 53.12 & 42.24 & 0.73 & 0.64 & 0.45 & 0.44 & 0.26 & 0.22 & 0.09 & 0.03 & 0.02 & 0.01 & 0.01 \\
\hline
\end{tabular}

${ }^{1}$ Data delivered from the producer Astra Technologia Betonu ${ }^{\circledR}$.

The role of aggregate was played by crushed CRT glass coming from discarded television sets and computer screens. CRT glass was delivered by Thornmann Recycling in already crushed form and was not subjected to any special pretreatment. According to the supplier (Thornmann Recycling, Warsaw, Poland), the discarded glass come from different parts of CRTs mixed together. For that reason, aggregate applied in the research consisted of all the parts of the kinescopes. During the majority of presented tests (Sections 3.1-3.3 of the paper), CRT glass was used in almost unchanged form (the only additional activity was removing sparse fractions bigger than $4 \mathrm{~mm}$ due to the small dimension of molds). During the listed tests, CRT glass particles of different size (but not bigger than $4 \mathrm{~mm}$ ) were used. Figure 1 shows the particle size distribution of the CRT glass. Section 3.4 of the paper describes the influence of size grain on the flexural and compressive strength of geopolymer. During the preparations for this part of the research, CRT glass was divided with the use of sieves into fractions $<0.5 \mathrm{~mm}$ and $0.5-4 \mathrm{~mm}$. 


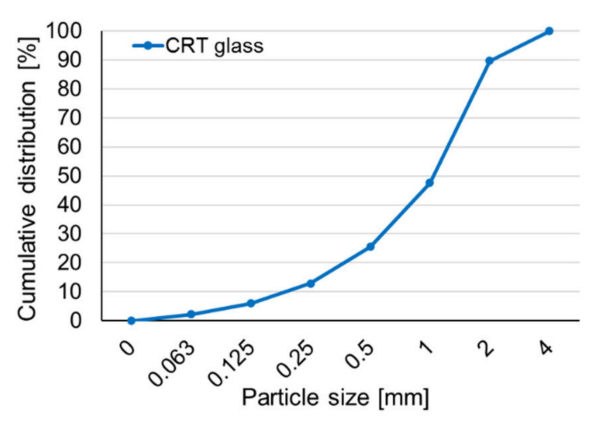

(a)

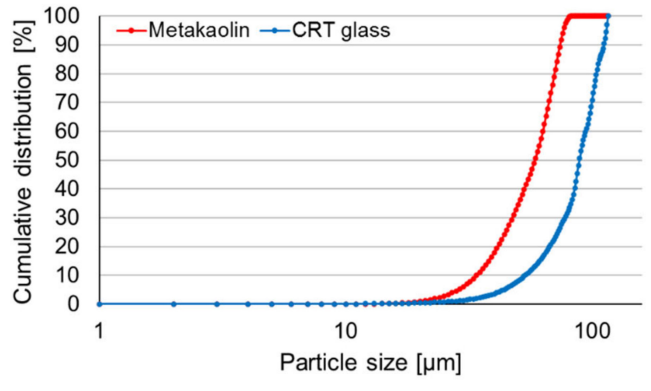

(b)

Figure 1. (a) The particle size distribution of CRT glass (b) The particle size distribution of metakaolin and fine particles of CRT glass.

The mixture of sodium hydroxide and sodium silicate was used as an activator. The water solution of sodium hydroxide was prepared minimum $24 \mathrm{~h}$ before mixture preparation with the use of demineralized water and $\mathrm{NaOH}$ pellets delivered by Chempur ${ }^{\circledR}$. The ratios of $\mathrm{NaOH}$ pellets and water were designed according to the demanded concentration of the solution. In tests described in Sections 3.1, 3.2 and 3.4, sodium silicate of concentration $10 \mathrm{~mol} / \mathrm{L}$ was used. Section 3.4, describing the influence of $\mathrm{NaOH}$ concentration of flexural and compressive strength, required preparing additional $\mathrm{NaOH}$ solutions of concentrations 6,8 and $12 \mathrm{~mol} / \mathrm{L}$. Sodium silicate solution was delivered by the producer Rudniki Z.Ch. S.A. ${ }^{\circledR}$. According to data given by the producer, the $\mathrm{SiO}_{2}$ to $\mathrm{Na}_{2} \mathrm{O}$ ratio can range between 2.4 and 2.6, the minimum content of oxides $\left(\mathrm{SiO}_{2}\right.$ and $\left.\mathrm{Na}_{2} \mathrm{O}\right)$ is $39 \%$, and the density at $20^{\circ} \mathrm{C}$ varies between 1.45 and $1.48 \mathrm{~g} / \mathrm{cm}^{3}$.

\subsection{Preparation of the Mixtures-General Information}

All mixtures were prepared according to the same procedure. Metakaolin and CRT glass were mixed. Separately, sodium silicate and sodium hydroxide were mixed for 5 min with the use of magnetic stirrer. Next, all ingredients were mixed with the use of a mechanical mixer. The mixture was placed in prismatic molds of dimensions $40 \times 40 \times 160 \mathrm{~mm}$ and covered tightly. Samples cured at elevated temperature (see Sections 3.1 and 3.2 of the paper) were placed in a climatic chamber at temperature $40{ }^{\circ} \mathrm{C}$ or $60{ }^{\circ} \mathrm{C}$ and humidity $60 \%$ for the first $24 \mathrm{~h}$, then these samples were demolded and kept at the room temperature in the laboratory. By contrast, samples which were cured all the time at the room temperature (except of series 20C I, in Section 3.2) were demolded just before testing (after 7 days). All samples described in the following paper were tested after 7 days of curing. Just before strength tests samples were weighed and measured which allowed us to establish the density of each sample.

\subsection{Preparation of the Mixtures_-Varying Factor: CRT Glass Content}

The main goal of the preliminary tests was to establish the influence of CRT glass content on flexural and compressive strength. Samples were made of eight mixtures containing different metakaolin to CRT glass mass ratios. Three samples were taken from each mixture. The exact composition of each mixture is given in Table 2. The main differentiating factor is the CRT glass content. The following mixtures are named as $\mathrm{M} / \mathrm{G}$ where $M$ stands for the metakaolin percentage content (calculated by mass), and $G$ stands for the CRT glass percentage content. The number of activators was adjusted to provide possible similar metakaolin to activators ratios within the following mixtures. The need for the adjustment of workability is the main reason for some small inequalities in the activator content. Sodium silicate to sodium hydroxide ratio was kept constant in all mixtures. The CRT glass particle sizes ranged from 0 to $4 \mathrm{~mm}$. All samples were cured at $60{ }^{\circ} \mathrm{C}$ for the first $24 \mathrm{~h}$. These particular curing conditions were chosen for preliminary tests since, according to scientific papers, the temperature of $60{ }^{\circ} \mathrm{C}$ results in high compressive strength of geopolymer, and there is no significant profit in using higher temperatures [54-57]. 
Table 2. Mixtures compositions.

\begin{tabular}{|c|c|c|c|c|c|c|}
\hline Mixture & $\begin{array}{l}\text { Metakaolin } \\
{\left[\mathrm{kg} / \mathrm{m}^{3}\right]}\end{array}$ & $\begin{array}{c}\text { CRT } \\
{\left[\mathrm{kg} / \mathrm{m}^{3}\right]}\end{array}$ & $\begin{array}{l}\text { Sodium } \\
\text { Silicate } \\
{\left[\mathrm{kg} / \mathrm{m}^{3}\right]}\end{array}$ & $\begin{array}{c}\mathrm{NaOH} \\
{\left[\mathrm{kg} / \mathrm{m}^{3}\right]}\end{array}$ & $\underset{[-]}{\mathrm{Si} / \mathrm{Al}^{1}}$ & $\underset{[-]}{\mathrm{Na} / \mathrm{Al}^{1}}$ \\
\hline $\begin{array}{l}M / G \\
25 / 75\end{array}$ & 524 & 1572 & 314 & 157 & 1.40 & 0.55 \\
\hline $\begin{array}{c}M / G \\
33 / 67\end{array}$ & 657 & 1335 & 365 & 182 & 1.37 & 0.51 \\
\hline $\begin{array}{l}M / G \\
40 / 60\end{array}$ & 755 & 1133 & 417 & 208 & 1.37 & 0.50 \\
\hline $\begin{array}{l}M / G \\
50 / 50\end{array}$ & 898 & 898 & 449 & 225 & 1.34 & 0.46 \\
\hline $\begin{array}{l}M / G \\
60 / 40\end{array}$ & 995 & 663 & 521 & 260 & 1.36 & 0.48 \\
\hline $\begin{array}{l}M / G \\
67 / 33\end{array}$ & 1037 & 510 & 553 & 276 & 1.36 & 0.49 \\
\hline $\begin{array}{c}M / G \\
75 / 25\end{array}$ & 1078 & 359 & 586 & 293 & 1.37 & 0.48 \\
\hline $\begin{array}{c}\mathrm{M} / \mathrm{G} \\
100 / 0\end{array}$ & 1083 & 0 & 675 & 337 & 1.41 & 0.57 \\
\hline
\end{tabular}

\subsection{Preparation of the Mixtures-Varying Factor: Curing Temperature}

The main goal of this part of the research was to define the influence of curing temperature on flexural and compressive strength of geopolymer made of one chosen mixture M/G 50/50 (see Table 2). As in the previous test, the CRT glass particle sizes ranged from 0 to $4 \mathrm{~mm}$. In the previous test all samples were cured for the first $24 \mathrm{~h}$ at $60^{\circ} \mathrm{C}$ and then at room temperature. In the current test, samples were cured at four different conditions: at room temperature with demolding after $24 \mathrm{~h}$ (later in the text this series was designed as $20^{\circ} \mathrm{C} \mathrm{I}$ ), at room temperature with demolding after 7 days (later designed as $\left.20{ }^{\circ} \mathrm{C} \mathrm{II}\right)$, for the first $24 \mathrm{~h}$ at $40^{\circ} \mathrm{C}\left(40^{\circ} \mathrm{C}\right)$ and for the first $24 \mathrm{~h}$ at $60{ }^{\circ} \mathrm{C}\left(60^{\circ} \mathrm{C}\right)$. Each series comprised 3 samples.

\subsection{Preparation of the Mixtures_-Varying Factor: NaOH Concentration}

This part of the research was done to establish the influence of sodium hydroxide concentration on flexural and compressive strength. The mixture composition coincided with mixture M/G 50/50. Samples were cured all the time at room temperature with demolding after 7 days (the curing method assigned as $20{ }^{\circ} \mathrm{C}$ II from Section 2.3 of the paper). In previous tests, $\mathrm{NaOH}$ of concentration $10 \mathrm{~mol} / \mathrm{L}$ was used. In this part, three additional mixtures containing sodium hydroxide of concentrations 6,8 and $12 \mathrm{~mol} / \mathrm{L}$ were prepared. The CRT glass particle sizes ranged from 0 to $4 \mathrm{~mm}$. Each series comprised 4 samples.

\subsection{Preparation of the Mixtures_-Varying Factor: CRT Glass Particle Distribution}

The last part of the research was carried out to define the influence of CRT glass particles size on flexural and compressive strength of geopolymer. As a result of sieving, CRT glass grains were divided into two groups depending on the size of glass grains: less than $0.5 \mathrm{~mm}$ and 0.5 to $4 \mathrm{~mm}$. The quantities of ingredients were selected in accordance with the mixture M/G 50/50. One mixture contained glass grains of size $<0.5 \mathrm{~mm}$, the second contained glass grains ranging from 0.5 to $4 \mathrm{~mm}$. Results were compared with results of samples containing glass grains of size $<4 \mathrm{~mm}$. The visual comparison of CRT glass of different fractions is presented in Figure 2. All samples were cured at the room temperature and demolded after 7 days. The concentration of $\mathrm{NaOH}$ was equal to $10 \mathrm{~mol} / \mathrm{L}$. Each series comprised 4 samples. 


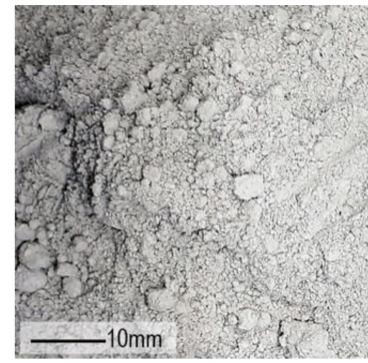

(a)

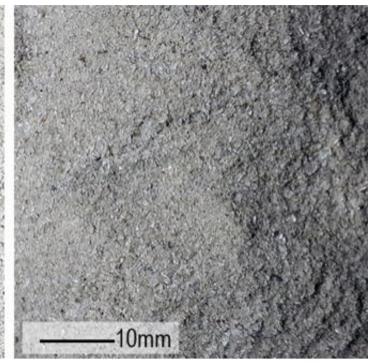

(b)

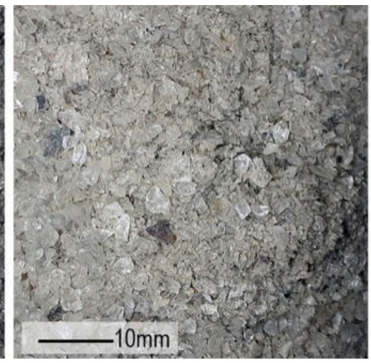

(c)

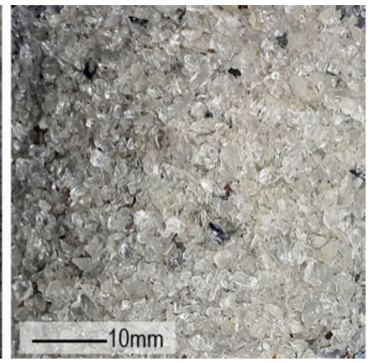

(d)

Figure 2. Dry ingredients of a mixture: (a) Metakaolin; (b) CRT glass $<0.5 \mathrm{~mm}$; (c) CRT glass $<4 \mathrm{~mm}$; (d) CRT glass $0.5-4 \mathrm{~mm}$.

\subsection{Test Procedures}

All samples had a prismatic shape of dimensions $40 \times 40 \times 160 \mathrm{~mm}$. Both flexural and compressive strength tests were performed on Strength tests machine Controls ${ }^{\circledR}$ Model 65-L27C12 Serial no 12020060 (Controls, Milan, Italy) according to procedure given in the European standard EN 196-1 [58]. In the first step, prismatic specimens were subjected to the three-points flexural test. The force was subjected in the middle of the specimen's length and the spacing of the supports was equal to $100 \mathrm{~mm}$. The compressive strength test was carried out on halves of samples broken during the flexural strength test through the metal plates of dimensions $40 \times 40 \mathrm{~mm}$. The testing process is shown in Figure 3 .

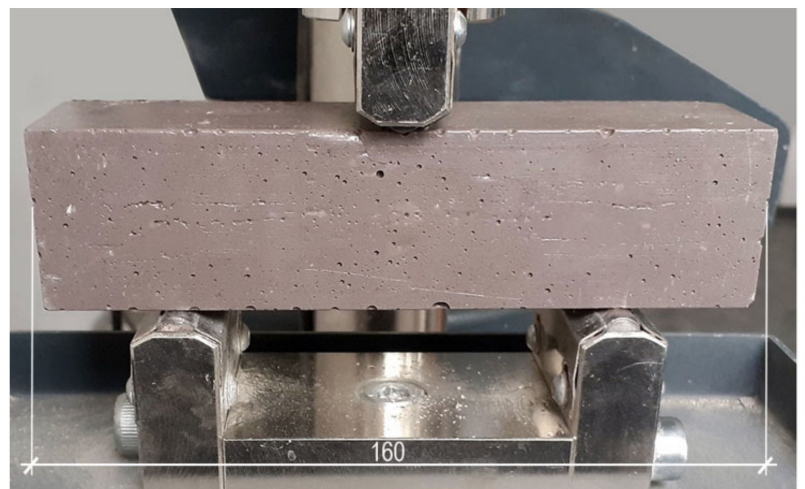

(a)

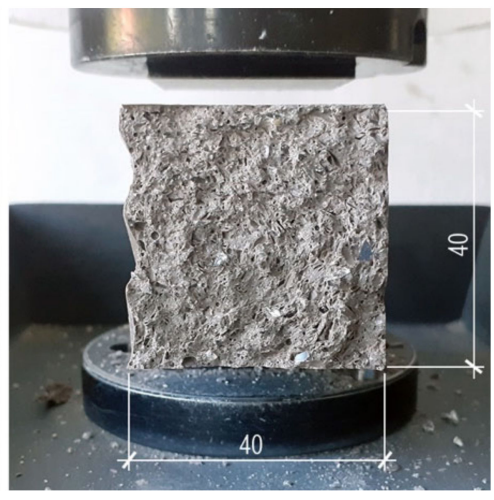

(b)

Figure 3. Geopolymer beam subjected to: (a) Flexural strength test; (b) Compressive strength test.

\section{Results}

All strength test results are presented in the form of bar charts. Each bar (as well as the value above the bar) represents the average value of flexural or compressive strength obtained by samples made of the following mixtures. The black segment in the upper part of each bar represents, successively, the lowest and highest value of strength obtained in each series. The number of tested samples is depicted in sections below since it varied depending on investigated feature.

\subsection{Preliminary Tests-CRT Glass Content}

Figure 4 depicts that there is no visible dependence between CRT glass content and flexural or compressive strength of geopolymer, determined in three-points flexural test according to European standard EN 196-1 [58]. Flexural and compressive strength tests were conducted on three and six samples, respectively. All series of samples achieved similar results. The only visible values are the lowest flexural strength of samples from series M/G 67/33 and lowest compressive strength of samples made of mixture M/G $75 / 25$. Both the highest flexural and compressive strength were obtained by samples made 
of mixture $\mathrm{M} / \mathrm{G} 50 / 50$. Table 3 contains the standard deviation and coefficient of variation of flexural and compressive strength results. For all compressive strength results, the coefficient of standard deviation is smaller than $10 \%$. In the case of flexural strength, the coefficient of standard deviation exceeds the value of 10\% for mixture M/G 67/33 (19\%). Since CRT glass content was not the only varying factor (the number of activators was being changed to provide adequate workability of the mixture, see Section 2.3), authors are treating the preliminary tests as results of eight different mixtures. Nevertheless, the changing CRT glass content is the most distinctive feature of presented mixtures. High strength results and optimal content of CRT glass were reasons why mixture M/G 50/50 was chosen for the next steps of the research.

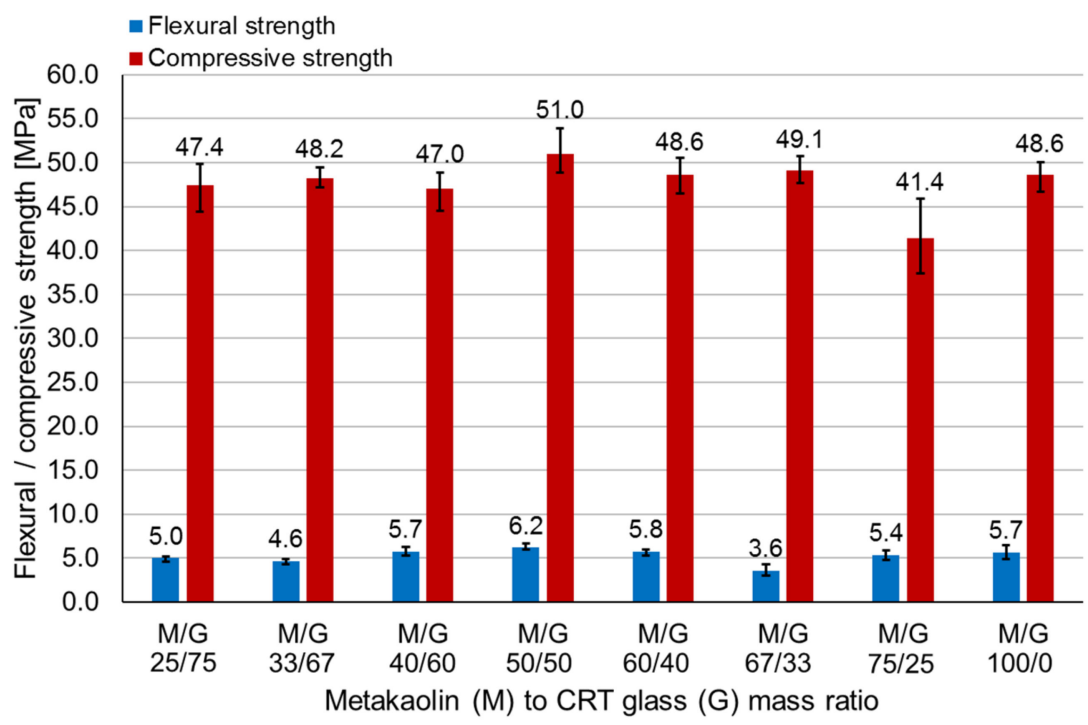

Figure 4. Flexural and compressive strength of geopolymer with different CRT glass content. 1158.94 piks.

Table 3. Standard deviation and coefficient of variation of flexural and compressive strength results.

\begin{tabular}{ccccccccc}
\hline $\begin{array}{c}\text { Standard } \\
\text { Deviation [-] } \\
\text { (Coeff. of } \\
\text { Variation [\%]) }\end{array}$ & M/G 25/75 & M/G 33/67 & M/G 40/60 & M/G 50/50 & M/G 60/40 & M/G 67/33 & M/G 75/25 & M/G 100/0 \\
\hline Flexural strength & 0.34 & 0.28 & 0.53 & 0.39 & 0.38 & 0.68 & 0.55 & 0.82 \\
& $(6.9)$ & $(6.1)$ & $(9.3)$ & $(6.3)$ & $(6.7)$ & $(19.0)$ & $(10.3)$ & $(14.5)$ \\
\hline Compressive & 2.44 & 1.11 & 2.06 & 2.41 & 2.02 & 1.35 & 3.49 & 1.41 \\
strength & $(5.2)$ & $(2.3)$ & $(4.4)$ & $(4.7)$ & $(4.1)$ & $(2.8)$ & $(8.4)$ & $(2.9)$ \\
\hline
\end{tabular}

Table 4 presents the average density of samples made of mixtures containing different CRT glass content. Each density from the Table is the average value obtained from three determinations (all samples from each series). According to data given in Table 4, density increases steadily with the increase of CRT glass content.

Table 4. The average density of geopolymer with different CRT glass content.

\begin{tabular}{ccccccccc}
\hline $\begin{array}{c}\text { Samples Made of } \\
\text { a Mixture }\end{array}$ & M/G 25/75 & M/G 33/67 & M/G 40/60 & M/G 50/50 & M/G 60/40 & M/G 67/33 & M/G 75/25 & M/G 100/0 \\
\hline Density $\left[\mathrm{kg} / \mathrm{m}^{3}\right]$ & 2090 & 1960 & 1940 & 1920 & 1770 & 1720 & 1690 & 1500 \\
\hline
\end{tabular}




\subsection{Curing Conditions}

Flexural and compressive strength tests were conducted on three and six samples respectively. According to the diagram shown in Figure 5, flexural strength increases monotonically with the increase of the curing temperature while the influence of the curing temperature on the compressive strength is almost negligible. Samples cured at $20^{\circ} \mathrm{C}$ and demolded after $24 \mathrm{~h}$ (series $20^{\circ} \mathrm{C} \mathrm{I}$ ) obtained significantly smaller flexural and compressive strength than the other samples. Samples from that series were affected by visible shrinkage which caused a net of surface cracks and deformation of the shape of samples. The deterioration of samples from series $20^{\circ} \mathrm{C}$ I was caused probably by too rapid contact with the air after the demolding. Samples cured at room temperature were not hard enough, and the process of geopolymerization was in the too early phase, so the contact with the air caused rapid drying of the extent of the water which led to the shrinkage. Samples cured at elevated temperatures $\left(40^{\circ} \mathrm{C}\right.$ and $\left.60^{\circ} \mathrm{C}\right)$ for the first $24 \mathrm{~h}$ were well developed since they were not affected by premature demolding. After an analysis of results, curing at the room temperature combined with demolding after seven days was considered as an optimal even though the strength results were most unstable. It was decided that economic benefits (the lack of elevated temperature) combined with good flexural and compressive strength make the series $20^{\circ} \mathrm{C}$ II the best one for further stages of the research.

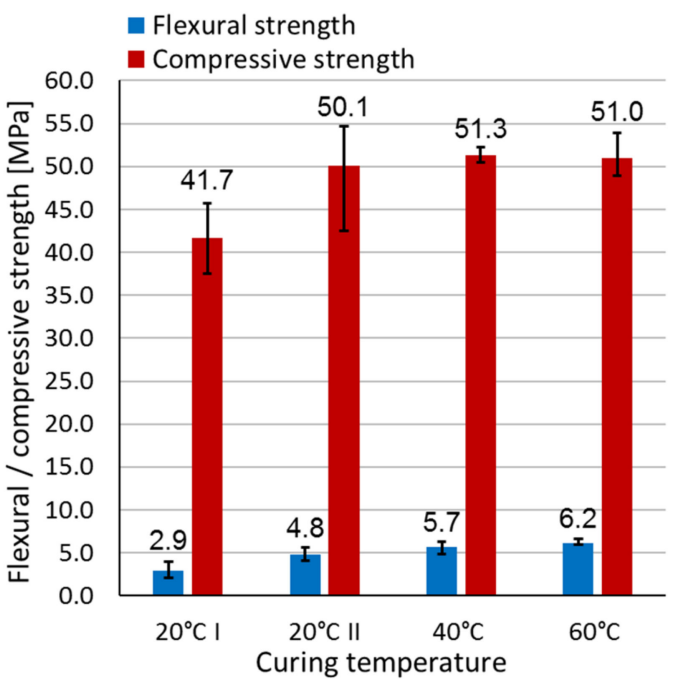

Figure 5. Flexural and compressive strength of geopolymer cured at different temperatures.

Table 5 contains the standard deviation and coefficient of variation of flexural and compressive strength results. Table 6 presents the average value of density obtained from three determinations (all samples from each series). The content of Table 6 indicates that there is no monotonic dependence between curing temperature and the final density of a geopolymer. Samples from series $20^{\circ} \mathrm{C} \mathrm{I}, 40^{\circ} \mathrm{C}$ and $60^{\circ} \mathrm{C}$ had very similar densities at the seventh day of curing. By contrast, there is strict dependence between the time of demolding and density. The density of samples demolded after seven days was considerably higher than the density of samples demolded after $24 \mathrm{~h}$. Samples demolded after $24 \mathrm{~h}$ had for the rest six days of curing contact with the air what allowed for the evaporation of the extent water what probably states the major reason for the difference in density. 
Table 5. Standard deviation and coefficient of variation of flexural and compressive strength results.

\begin{tabular}{ccccc}
\hline $\begin{array}{c}\text { Standard Deviation [-] } \\
\text { (Coeff. of Variation [\%]) }\end{array}$ & $\mathbf{2 0}{ }^{\circ} \mathbf{C ~} \mathbf{~}$ & $\mathbf{2 0}{ }^{\circ} \mathbf{C ~ I I ~}$ & $\mathbf{4 0}{ }^{\circ} \mathbf{C}$ & $\mathbf{6 0}{ }^{\circ} \mathbf{C}$ \\
\hline Flexural strength & 0.95 & 0.75 & 0.77 & 0.39 \\
& $(32.1)$ & $(15.8)$ & $(13.5)$ & $(6.3)$ \\
\hline Compressive strength & 3.67 & 5.34 & 0.77 & 2.41 \\
& $(8.8)$ & $(10.6)$ & $(1.5)$ & $(4.7)$ \\
\hline
\end{tabular}

Table 6. The average density of geopolymer containing $\mathrm{NaOH}$ of different concentration.

\begin{tabular}{ccccc}
\hline Curing Temperature & $\mathbf{2 0}{ }^{\circ} \mathbf{C} \mathbf{~}$ & $\mathbf{2 0}{ }^{\circ} \mathbf{C}$ II & $\mathbf{4 0}{ }^{\circ} \mathbf{C}$ & $\mathbf{6 0}{ }^{\circ} \mathbf{C}$ \\
\hline Density $\left[\mathrm{kg} / \mathrm{m}^{3}\right]$ & 1910 & 2040 & 1890 & 1920 \\
\hline
\end{tabular}

\section{3. $\mathrm{NaOH}$ Concentration}

Flexural and compressive strength tests were conducted on four and eight samples, respectively. According to the results (shown in Figure 6), the compressive strength grows with the increase of $\mathrm{NaOH}$ concentration. The most significant growth of compressive strength $(43 \%)$ was observed between samples activated with $8 \mathrm{~mol} / \mathrm{L} \mathrm{NaOH}$ and $10 \mathrm{~mol} / \mathrm{L}$ $\mathrm{NaOH}$. The further increase in strength is negligible. The flexural strength increases initially with the increase of $\mathrm{NaOH}$ concentration but only to the molarity $10 \mathrm{~mol} / \mathrm{L}$. Then, the flexural strength decreases. The authors assessed the sodium hydroxide of concentration $10 \mathrm{~mol} / \mathrm{L}$ as optimal since it allowed to obtain the highest flexural strength and compressive strength close to the highest one. As shown in the Table 7, the coefficient of standard deviation was smaller than $10 \%$ for results of all series of samples. Except for samples activated with $\mathrm{NaOH}$ of concentration $8 \mathrm{~mol} / \mathrm{L}$, the compressive strength results were more stable than flexural strength results.

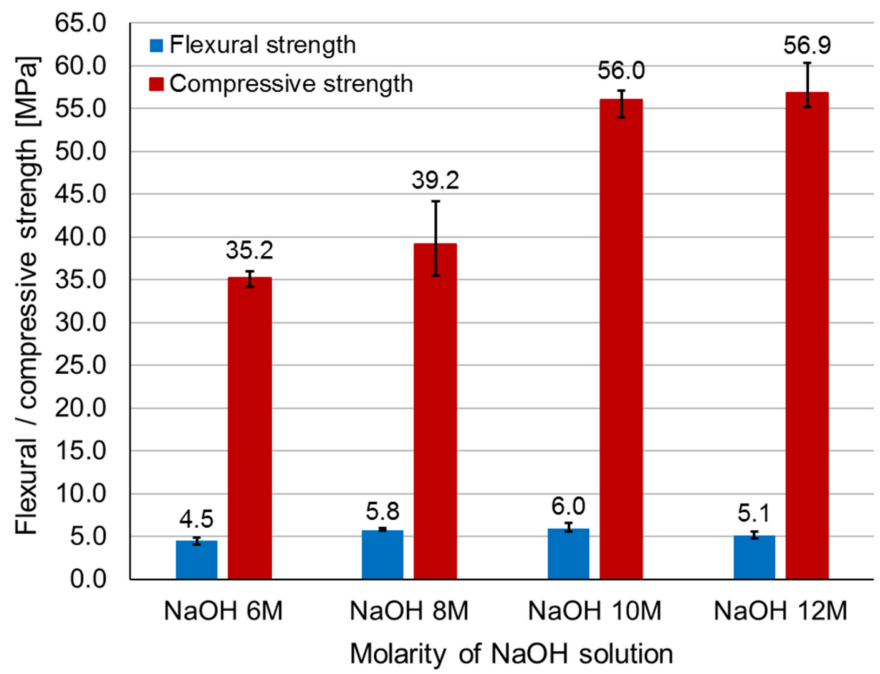

Figure 6. Flexural and compressive strength of geopolymer activated with $\mathrm{NaOH}$ of varying concentrations.

The results obtained by samples activated with $10 \mathrm{~mol} / \mathrm{L} \mathrm{NaOH}$ do not entirely match results presented in Section 3.2 cured at room temperature $\left(20{ }^{\circ} \mathrm{C} \mathrm{II}\right)$, even though the mixture composition and curing regime was the same in both series. These two series were done in two turns, and the CRT glass from different batches was used during the research which could cause some inequalities in strength results.

The summary of average densities presented in Table 8 indicates that this parameter tends to increase slightly with the increase of sodium hydroxide concentration. Each 
density from the Table is the average value obtained from four determinations (all samples from each series). However, the differences are small, and in case of samples activated with $\mathrm{NaOH}$ of concentration $12 \mathrm{~mol} / \mathrm{L}$, this tendency is disturbed. It may be caused by worse compaction of samples from this series. This would also be an explanation for lower flexural strength results.

Table 7. Standard deviation and coefficient of variation of flexural and compressive strength results.

\begin{tabular}{ccccc}
\hline $\begin{array}{c}\text { Standard Deviation [-] } \\
\text { (Coeff. of Variation [\%]) }\end{array}$ & NaOH 6 M & NaOH 8 M & NaOH 10 M & NaOH 12 M \\
\hline Flexural strength & 0.35 & 0.16 & 0.48 & 0.39 \\
& $(7.8)$ & $(2.8)$ & $(8.1)$ & $(7.7)$ \\
\hline \multirow{2}{*}{ Compressive strength } & 0.71 & 3.34 & 1.42 & 1.81 \\
& $(2.0)$ & $(8.5)$ & $(2.5)$ & $(3.2)$ \\
\hline
\end{tabular}

Table 8. The average density of geopolymer containing $\mathrm{NaOH}$ of different concentration.

\begin{tabular}{ccccc}
\hline $\mathbf{N a O H}$ & $6 \mathrm{~mol} / \mathrm{L}$ & $\mathbf{8 ~ m o l} / \mathrm{L}$ & $\mathbf{1 0 ~ m o l} / \mathrm{L}$ & $12 \mathrm{~mol} / \mathrm{L}$ \\
\hline Density $\left[\mathrm{kg} / \mathrm{m}^{3}\right]$ & 1990 & 2010 & 2030 & 2020 \\
\hline
\end{tabular}

\subsection{CRT Glass Particle Sizes}

The dependence between CRT glass size and geopolymer strength is shown in Figure 7. Flexural and compressive strength tests were conducted on four and eight samples, respectively. The differences in flexural and compressive strength between geopolymer samples containing different fractions of CRT glass particles are not significant. The highest flexural strength was obtained by geopolymer with the full range of CRT glass particles fractions. Samples containing the smallest glass particles $(<0.5 \mathrm{~mm})$ achieved $\sim 4 \%$ lower compressive strength than two other series of samples. The broken surfaces of samples containing different CRT glass sizes are presented in Figure 8.

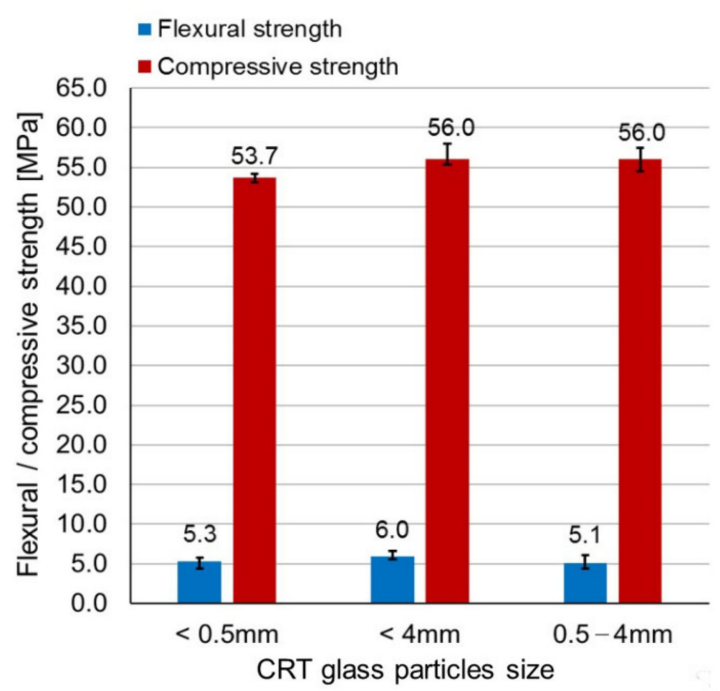

Figure 7. Flexural and compressive strength of geopolymer containing CRT glass of varying particle sizes. 


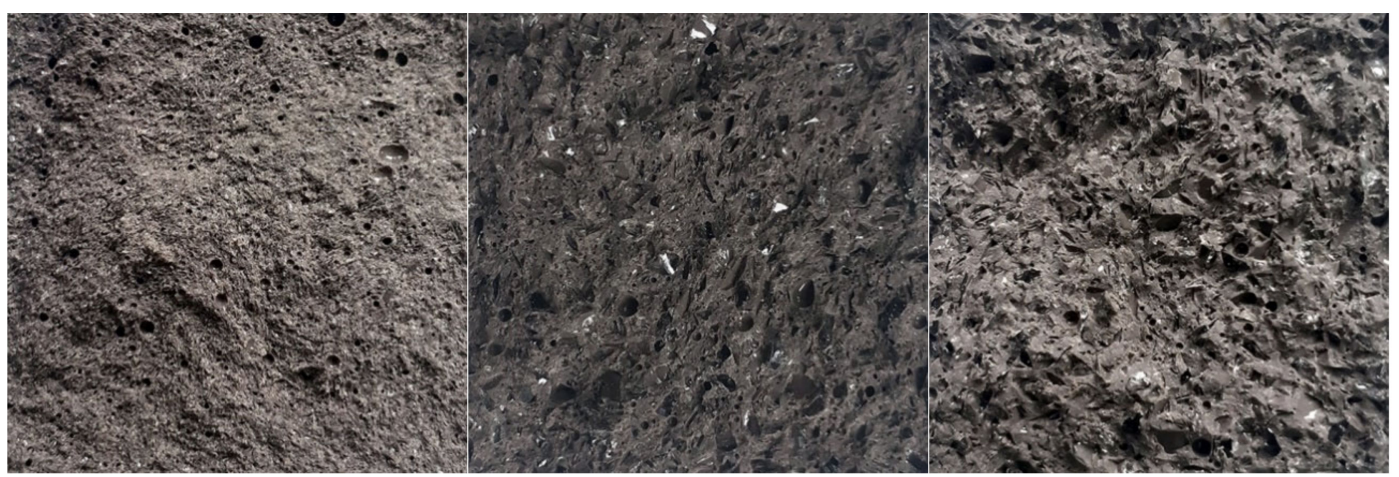

(a)

(b)

(c)

Figure 8. Geopolymer sample broken during flexural strength test, containing glass of different grain sizes: (a) $<0.5 \mathrm{~mm}$; (b) $<4 \mathrm{~mm}$; (c) $0.5-4 \mathrm{~mm}$.

Table 9 contains the standard deviation and coefficient of variation of flexural and compressive strength results. Table 10 presents the average value of density obtained from four determinations (all samples from each series). According to the content of Table 10, samples containing greater CRT glass particles are characterized by higher density. Geopolymer containing CRT glass particles of size $<0.5 \mathrm{~mm}$ had the lowest density while geopolymer containing CRT glass particles ranging from 0.5 to $4 \mathrm{~mm}$ had the highest density.

Table 9. Standard deviation and coefficient of variation of flexural and compressive strength results.

\begin{tabular}{cccc}
\hline $\begin{array}{c}\text { Standard Deviation [-] } \\
\text { (Coeff. of Variation [\%]) }\end{array}$ & $<\mathbf{0 . 5} \mathbf{~ m m}$ & $<\mathbf{4 ~} \mathbf{m}$ & $\mathbf{0 . 5} \mathbf{- 4} \mathbf{~} \mathbf{m}$ \\
\hline Flexural strength & 0.63 & 0.48 & 0.77 \\
& $(11.7)$ & $(8.1)$ & $(15.2)$ \\
\hline \multirow{2}{*}{ Compressive strength } & 0.42 & 1.42 & 1.22 \\
& $(0.8)$ & $(2.5)$ & $(2.2)$ \\
\hline
\end{tabular}

Table 10. The average density of geopolymer containing CRT glass of different particle size.

\begin{tabular}{cccc}
\hline CRT Glass Particle Size & $<0.5 \mathbf{~ m m}$ & $<4 \mathbf{~ m m}$ & $\mathbf{0 . 5}-\mathbf{4 ~ \mathbf { m m }}$ \\
\hline Density $\left[\mathrm{kg} / \mathrm{m}^{3}\right]$ & 1980 & 2030 & 2070 \\
\hline
\end{tabular}

\section{Discussion}

\subsection{Preliminary Tests-CRT Glass Content}

It is difficult to compare the presented results with the literature since there is a lack of similar tests. Tomas Opletal [52] uses different metakaolin to CRT glass ratio, but it is not the only changing factor. Metakaolin to CRT glass ratio ranges from 1:2 to 1:7, but simultaneously CRT glass size and activator to raw materials ratios are changing. The only results which can be reasonably compared indicate that compressive strength decreases with the increase of CRT glass content. In the first case, compressive strength reduces by $11 \%$ while the CRT glass ratio to metakaolin increases from 3:1 to 7:1. In the second pair of samples (of different composition than the first pair) compressive strength decreases by $6 \%$ while CRT glass ratio to metakaolin increases from 2:1 to 3:1.

According to the preliminary test results, there is no explicit dependence between the CRT glass content and flexural or compressive strength. Some particular series achieved smaller strength, as for instance samples made of mixture M/G 67/33 had significantly lower flexural strength than the other samples. Due to the changing consistency, the CRT glass content was not the only varying factor (the amount of fluid activator was adjusted as well). The increasing amount of liquid in samples with smaller CRT glass content could 
reduce strength. That is one possible reason for the lack of dependence between CRT glass content and flexural strength. The other possibility is that the main factor responsible for the mechanical behavior is hardened metakaolin matrix, while the CRT glass aggregate is acting mainly as a filler (expect of the finest fractions which should react with activators). The pure metakaolin samples achieved the similar strength to the other samples. In this line of reasoning, even in samples containing $75 \%$ of CRT glass, the amount of hardened metakaolin matrix could be enough to maintain high strength. The exact investigation of the microstructure would probably help to explain this behavior. Such research is planned in the future.

That part of the research gives the conclusion that the significant amount of CRT glass can be recycled in metakaolin-based geopolymer not altering its strength. On the other hand, increasing CRT glass content has a clear negative impact on the density of geopolymer, which is also an important factor, especially in the case of building material. Besides, the amount of CRT glass content can be crucial for lead leaching, which should be examined in the future. In that case, samples containing less CRT glass are more likely to meet the limits. So far, authors decided that within eight presented mixtures, mixture M/G $50 / 50$ is optimal considering flexural and compressive strength, the stability of results and the amount of CRT glass recycled as an aggregate in the geopolymer matrix. This mixture was chosen for further tests.

\subsection{Curing Conditions}

Even though the topic of the influence of curing temperature on the strength of metakaolin-based geopolymer was widely raised in the past, scientists still do not agree on that matter. Alonso et al. (2011) [59] reports the substantial increase in flexural strength when the temperature of curing increases from $35^{\circ} \mathrm{C}$ to $45^{\circ} \mathrm{C}$. The other difference between samples cured at $45^{\circ} \mathrm{C}$ and $60^{\circ} \mathrm{C}$ is much less significant. A similar observation has been made by Riahi et al. (2020) [60] in the case of compressive strength. Samples cured at $50{ }^{\circ} \mathrm{C}$ obtained much higher strength that samples cured at room temperature. For samples cured at $75{ }^{\circ} \mathrm{C}$, the compressive strength decreases abruptly. By contrast, Lancellotti et al. (2013) [61] recommends curing at room temperature since no improvement of geopolymer properties was observed while cured at elevated temperature $\left(50{ }^{\circ} \mathrm{C}\right)$. Sun et al. (2019) [62] observed that on the initial stage of curing, the elevated temperature enhances the compressive and flexural strength. After seven days of curing, the most significant difference in compressive strength was registered between samples cured at $20{ }^{\circ} \mathrm{C}, 30^{\circ} \mathrm{C}$ and $40^{\circ} \mathrm{C}$. However, the dependencies are changing in the long term. Scientists observed that after one year, the highest compressive strength was obtained by samples cured at $20^{\circ} \mathrm{C}$. The elevated temperature helps in the dissolution of the metakaolin and formation of reaction products at the early stages of the process which increases early age strength. However, acceleration of processes influences the quality of final products of a reaction negatively and, in effect, the microstructure [62]. Yuan et al. (2016) [63] presents subjecting of samples to the elevated temperatures $50{ }^{\circ} \mathrm{C}$ to $90{ }^{\circ} \mathrm{C}$ by the whole period of curing. In this case, the compressive strength increases with the increase of curing temperature except for samples cured at $90{ }^{\circ} \mathrm{C}$ for which strength falls. Authors explain that elevated temperature accelerates geopolymerization, leading to the formation of the compact structure of improved strength [63]. A very similar tendency was observed by Mo et al. (2014) [55] who described that compressive strength was increasing with the increase of curing temperature, but for the highest tested temperatures $\left(80^{\circ} \mathrm{C}\right.$ and $\left.100{ }^{\circ} \mathrm{C}\right)$, the strength begins to fawn. Mo et al. (2014) [55] indicates, that at low-temperature metakaolin dissolute too slowly and there is not enough $\mathrm{Al}$ particles dissolved from amorphous phases to polymerize with amorphous $\mathrm{Si}$ and to form a sufficient amount of aluminosilicate gels. The water and sol phase existing in the structure influences strength negatively. The problem is solved by the increase of the curing temperature, which promotes dissolution of metakaolin and formation of geopolymer gel. Scientists explain that compressive strength drops for higher curing temperatures because metakaolin particles are reacting too fast, and 
the geopolymer gel covers unreacted particles, preventing further dissolution. Additionally, too high temperature leads to the shrinkage and microcracking [55]. According to Ekaputri et al. (2017) [57], curing at elevated temperatures for the first $24 \mathrm{~h}$ increases both short and long term compressive strength of metakaolin-based geopolymer. Tests were done on samples cured at $20,40,60$ and $80^{\circ} \mathrm{C}$. However, the differences in compressive strength of samples cured in different conditions were very small $(\sim 1-2 \%)$. The increasing tendency was also registered in the case of the tensile splitting strength, but here also, the differences were not significant. Completely different results are presented by Rovnanik (2010) [64]. According to this author, the flexural and compressive strength increases with the increase of the curing temperature only after 1 day of curing. Then, the strength of samples cured at $20^{\circ} \mathrm{C}$ and $40{ }^{\circ} \mathrm{C}$ surpasses the strength of samples cured at $60^{\circ} \mathrm{C}$ and $80^{\circ} \mathrm{C}$. What is more, according to [64], samples cured at $10^{\circ} \mathrm{C}$ are hard enough to be tested only after seven days, but after 28 days they achieve the highest compressive and flexural strength. Bulk density decreases with the increase of curing temperature. Rovnanik (2010) [64] uses similar arguments to Sun et al. (2019) [62] explaining presented dependences. The high temperature helps developing high early strength but leads to greater porosity and worse compaction of samples affecting quality and causing lower long-term strength.

Results obtained in the following test are most similar to results presented by Ekaputri et al. (2017) [57] — the strength increases with the increase of the curing temperature, but differences are almost negligible. Indeed, long-term strength tests are essential to assess the further mechanical behavior of metakaolin-based geopolymer with CRT glass in the form of an aggregate. Results which were obtained so far lead to the conclusion that the optimal curing temperature is $20^{\circ} \mathrm{C}$ as long as samples are not demolded earlier than after seven days. The lack of elevated curing temperature is better from the economic and ecologic point of view. Additionally, compressive strength is almost as good as the compressive strength of samples cured at higher temperatures. The flexural strength is slightly smaller. Moreover, according to the data given by other scientists [62,64], the long-term strength of geopolymer cured at the room temperature is likely to surpass the strength of geopolymer cured at elevated temperature.

\section{3. $\mathrm{NaOH}$ Concentration}

According to Alonso et al. (2001) [59], the flexural strength of metakaolin-based geopolymer decreases steadily with the increase of sodium hydroxide concentration from $10 \mathrm{~mol} / \mathrm{L}$ to $18 \mathrm{~mol} / \mathrm{L}$. According to the scientists, the growth in $\mathrm{NaOH}$ concentration induces an increase in ions species concentration what effects in limited mobility of ions and finally, in delay in the formation of coagulated structures and polymer formation. Wang et al. (2005) [65] investigated flexural and compressive strength of metakaolin-based geopolymer cured at the room temperature and activated with $\mathrm{NaOH}$ of concentrations 4 , $6,8,10,12 \mathrm{~mol} / \mathrm{L}$. According to [65], flexural strength increases with the increase of $\mathrm{NaOH}$ concentration; however, in the case of samples activated by 8 and $10 \mathrm{~mol} / \mathrm{L}$ activator, the difference was negligible. This result is not convergent with results presented in the following paper where flexural strength of samples activated with $\mathrm{NaOH} 12 \mathrm{~mol} / \mathrm{L}$ is smaller than of samples activated with $\mathrm{NaOH} 8$ or $10 \mathrm{~mol} / \mathrm{L}$. Due to [65], the compressive strength increases with the increase of $\mathrm{NaOH}$ concentration, but for samples activated with 4,6 , and $8 \mathrm{~mol} / \mathrm{L}$ activators, the growth of strength is minimal. There is a sudden rise of compressive strength between samples activated with sodium hydroxide of 8 and $10 \mathrm{~mol} / \mathrm{L}$. Then, the compressive strength stabilizes. This part of results coincides with the current paper. The higher concentration of sodium hydroxide provides higher $\mathrm{pH}$ of the mixture what enhances dissolving process of metakaolin, next, increases inter-molecular bonding strength and, as an effect, leads to the creation of more compacted geopolymer with higher strength $[65,66]$. The increase of compaction is also visible in higher apparent density of the geopolymer [65]. Steveson et al. (2005) [66] also reports the growth of strength along with the increase of activator concentration within 7-12 mol/L, although, he observed the enlarging amount of unreacted particles simultaneously. The accelerated 
setting shortens the time needed for dissolution, which results in a greater quantity of unreacted particles [66]. Yao et al. (2009) [67] derives that the rate of reaction heat evolution at the first stage of the process rises with the increase of activator concentration. High concentrations of ions improve the dissolution of aluminosilicate but can be undesirable for polymerization. Authors indicate that $9 \mathrm{~mol} / \mathrm{L}$ is the optimal concentration within $\mathrm{NaOH}$ ranging from 7 to $12 \mathrm{~mol} / \mathrm{L}$.

Based on the obtained results, Authors decided that $10 \mathrm{~mol} / \mathrm{L}$ is an optimal $\mathrm{NaOH}$ concentration. Compressive strength of geopolymer activated with $\mathrm{NaOH}$ of concentration $10 \mathrm{~mol} / \mathrm{L}$ is substantially higher than of geopolymers activated with $\mathrm{NaOH}$ of lower concentrations and negligibly lower than of geopolymers activated with $12 \mathrm{~mol} / \mathrm{L} \mathrm{NaOH}$. The flexural strength obtained by these samples was the highest. Besides, higher concentrations of activators are related to financial and environmental costs.

\subsection{CRT Glass Particle Sizes}

The only publication concerning CRT used as an aggregate in metakaolin-based geopolymer found by the authors is the master's thesis of Tomas Opletal [52]. His work focuses mainly on geopolymer samples containing different fractions of CRT glass mixed in different mass ratios. The comparison of results of geopolymers containing CRT glass of sizes $0.5-2 \mathrm{~mm}$ and sizes $125-250 \mu \mathrm{m}$ in proportions $2: 1,1: 1$ and $1: 2(56.8 \mathrm{MPa}, 61.7 \mathrm{MPa}$, $54.9 \mathrm{MPa}$ ) shows that there is no direct dependence between CRT glass size and compressive strength. The difference between compressive strength of samples containing CRT of two sizes (1) $0.5-2 \mathrm{~mm}$ (2) $125-250 \mu \mathrm{m}$ and (1) $0.5-4 \mathrm{~mm}$ (2) $63-500 \mu \mathrm{m}$ is negligible. The highest compressive strength (111.6 MPa) was obtained by samples containing only fractions ranging from 2 to $4 \mathrm{~mm}$. Summarizing, results presented by [52] can be treated as similar to those shown in the following paper since the smallest compressive strength was achieved by geopolymer containing the highest amount of small CRT glass fractions. However, the tests are not entirely convergent which does not allow us to draw binding conclusions.

Since there is no substantial difference in strength, the we decided that in the further studies CRT glass of full range of a size $(<4 \mathrm{~mm})$ will be used. This solution is connected with the most limited labor input, which is correlated to the most limited time and financial costs while geopolymer is produced on a big scale.

Summarizing, further research will be done on metakaolin-based geopolymer containing $50 \%$ of CRT glass of particle size up to $4 \mathrm{~mm}$, activated with sodium hydroxide of concentration $10 \mathrm{~mol} / \mathrm{L}$ and cured at the room temperature. Among the nearest future goals will be the determination of long-term mechanical behavior and lead leaching examination. Results of both tests can influence decisions concerning the composition of the mixture and curing conditions. Further goals will concern bigger scale tests.

\section{Conclusions}

The main goal of the paper was to present basic characteristics (flexural and compressive strength and density) of metakaolin-based geopolymer with crushed CRT glass in the form of an aggregate. Tests were done on mixtures of different compositions, subjected to different curing conditions. The following conclusions were done:

1. The mixture containing metakaolin to CRT glass mass ratio equal to 1:1 is optimal since it combines a high level of use of CRT glass with, not very high density and good mechanical performance.

2. Geopolymer should be cured at the room temperature and demolded after seven days of curing. Such curing regime ensures high strength, lack of extent shrinkage and minimum costs.

3. An optimal sodium hydroxide concentration is $10 \mathrm{~mol} / \mathrm{L}$. Smaller concentrations influence the strength of the geopolymer negatively. Higher concentrations involve higher costs with no significant gain of strength.

4. CRT glass can be added to the mixture without any special treatment from the perspective of good mechanical performance. 
This paper presented a new type of geopolymer is a promising material which gives a new possibility of recycling CRT glass without any special pretreatment. According to mechanical performance, metakaolin-based geopolymer with CRT2 glass in the form of an aggregate can be treated as a building material of excellent properties. Further tests including possible toxic metals leaching, and long-term performance should be done in the nearest future to complete knowledge about this material.

Author Contributions: Conceptualization, M.G. and N.W.; methodology, M.G. and N.W.; validation, N.W., M.G. and J.K.; formal analysis, N.W. and M.G.; investigation, N.W.; resources, M.G.; data curation, N.W.; writing—original draft preparation, N.W.; writing—review and editing, M.G. and J.K.; visualization, N.W. and M.G.; supervision, M.G. and J.K.; project administration, M.G.; funding acquisition, M.G. All authors have read and agreed to the published version of the manuscript.

Funding: This research been prepared with the financial support of European Union's Horizon 2020 Research and Innovation Staff Exchange (RISE) program (Marie Skłodowska-Curie Actions) under grant agreement no. 645696, project REMINE (Reuse of Mining Waste into Innovative Geopolymericbased Structural Panels, Precast, Ready Mixes and Insitu Applications), Polish Ministry of Science and Higher Education project no. 341284/PnH /2016. The AC was funded by Silesian University of Technology (“Subwencja na utrzymanie potencjału badawczego").

Institutional Review Board Statement: Not applicable.

Informed Consent Statement: Not applicable.

Data Availability Statement: Data available on request due to restrictions eg privacy or ethical.

Acknowledgments: Authors thank Thornmann Recycling for supplying waste CRT glass and Tauron for supplying raw materials.

Conflicts of Interest: The authors declare no conflict of interest.

\section{References}

1. Poon, C. Management of CRT glass from discarded computer monitors and TV sets. Waste Manag. 2008, 28, 1499. [CrossRef] [PubMed]

2. Qi, Y.; Xiao, X.; Lu, Y.; Shu, J.; Wang, J.; Chen, M.; Shu, J. Cathode ray tubes glass recycling: A review. Sci. Total Environ. 2019, 650, 2842-2849. [CrossRef] [PubMed]

3. Yao, Z.; Ling, T.-C.; Sarker, P.; Su, W.; Liu, J.; Wu, W.; Tang, J. Recycling difficult-to-treat e-waste cathode-ray-tube glass as construction and building materials: A critical review. Renew. Sustain. Energy Rev. 2018, 81, 595-604. [CrossRef]

4. Davidovits, J. Geopolymer Chemistry and Applications, 4th ed.; Institut Géopolymère: Saint-Quentin, France, 2015.

5. Sandanayake, M.; Gunasekara, C.; Law, D.; Zhang, G.K.; Setunge, S.; Wanijuru, D. Sustainable criterion selection framework for green building materials-An optimisation based study of fly-ash Geopolymer concrete. Sustain. Mater. Technol. 2020, 25 , e00178. [CrossRef]

6. Obonyo, E.; Elie, K.; Melo, U.F.C.; Leonelli, C. Advancing the Use of Secondary Inputs in Geopolymer Binders for Sustainable Cementitious Composites: A Review. Sustainability 2011, 3, 410-423. [CrossRef]

7. Lin, K.-L.; Lo, K.; Cheng, T.-W.; Lin, W.-T.; Lin, Y.-W. Utilization of Silicon Carbide Sludge as Metakaolin-Based Geopolymer Materials. Sustainability 2020, 12, 7333. [CrossRef]

8. Van Jaarsveld, J.; Van Deventer, J.; Lorenzen, L. The potential use of geopolymeric materials to immobilise toxic metals: Part, I. Theory and applications. Miner. Eng. 1997, 10, 659-669. [CrossRef]

9. Palomo, Á.; Palacios, M. Alkali-activated cementitious materials: Alternative matrices for the immobilisation of hazardous wastes. Cem. Concr. Res. 2003, 33, 289-295. [CrossRef]

10. Ji, Z.; Su, L.; Pei, Y. Synthesis and toxic metals (Cd, Pb, and $\mathrm{Zn})$ immobilization properties of drinking water treatment residuals and metakaolin-based geopolymers. Mater. Chem. Phys. 2020, 242, 122535. [CrossRef]

11. Malolepszy, J.; Deja, J. Immobilization of heavy metal ions by the alkali activated slag cementitious materials. Stud. Environ. Sci. 1994, 60, 519-524.

12. Małolepszy, J.; Deja, J. Effect of Heavy Metals Immobilization on the Properties of Alkali Activated Slag Mortars; American Concrete Institution: Milwauke, MI, USA, 1995; Volume II, pp. 1087-1095.

13. Romero, D.; James, J.; Mora, R.; Hays, C.D. Study on the mechanical and environmental properties of concrete containing cathode ray tube glass aggregate. Waste Manag. 2013, 33, 1659-1666. [CrossRef] [PubMed]

14. Liu, H.-L.; Shi, J.-J.; Qu, H.-Q.; Ding, D. Feasibility of using recycled CRT funnel glass as partial replacement of high density magnetite sand in radiation shielding concrete. Trans. Nonferrous Met. Soc. China 2019, 29, 831-839. [CrossRef] 
15. Liu, T.; Qin, S.; Zou, D.; Song, W. Experimental investigation on the durability performances of concrete using cathode ray tube glass as fine aggregate under chloride ion penetration or sulfate attack. Constr. Build. Mater. 2018, 163, 634-642. [CrossRef]

16. Walczak, P.; Małolepszy, J.; Reben, M.; Rzepa, K. Mechanical Properties of Concrete Mortar Based on Mixture of CRT Glass Cullet and Fluidized Fly Ash. Procedia Eng. 2015, 108, 453-458. [CrossRef]

17. Pauzi, N.N.M.; Jamil, M.; Hamid, R.; Abdin, A.; Zain, M.F.M. Influence of spherical and crushed waste Cathode-Ray Tube (CRT) glass on lead $(\mathrm{Pb})$ leaching and mechanical properties of concrete. J. Build. Eng. 2019, 21, 421-428. [CrossRef]

18. Wei, H.; Zhou, A.; Liu, T.; Zou, D.; Jian, H. Dynamic and environmental performance of eco-friendly ultra-high performance concrete containing waste cathode ray tube glass as a substitution of river sand. Resour. Conserv. Recycl. 2020, $162,105021$. [CrossRef]

19. Zhao, H.; Poon, C.S.; Ling, T.-C. Utilizing recycled cathode ray tube funnel glass sand as river sand replacement in the high-density concrete. J. Clean. Prod. 2013, 51, 184-190. [CrossRef]

20. Liu, T.; Wei, H.; Zou, D.; Zhou, A.; Jian, H. Utilization of waste cathode ray tube funnel glass for ultra-high performance concrete. J. Clean. Prod. 2020, 249, 119333. [CrossRef]

21. Hilton, B.; Bawden, K.; Winnebeck, K.; Chandrasiri, C.; Ariyachandra, E.; Peethamparan, S. The functional and environmental performance of mixed cathode ray tubes and recycled glass as partial replacement for cement in concrete. Resour. Conserv. Recycl. 2019, 151, 104451. [CrossRef]

22. Ling, T.-C.; Poon, C.-S. A comparative study on the feasible use of recycled beverage and CRT funnel glass as fine aggregate in cement mortar. J. Clean. Prod. 2012, 29-30, 46-52. [CrossRef]

23. Ling, T.-C.; Poon, C.-S.; Lam, W.-S.; Chan, T.-P.; Fung, K.K.-L. Utilization of recycled cathode ray tubes glass in cement mortar for X-ray radiation-shielding applications. J. Hazard. Mater. 2012, 199-200, 321-327. [CrossRef] [PubMed]

24. Sopapan, P.; Laopaiboon, J.; Jaiboon, O.; Yenchai, C. Feasibility study of recycled CRT glass on elastic and radiation shielding properties used as X-ray and gamma-ray shielding materials. Prog. Nucl. Energy 2020, 119, 103149. [CrossRef]

25. Luhar, S.; Cheng, T.-W.; Nicolaides, D.; Luhar, I.; Panias, D.; Sakkas, K. Valorisation of glass waste for development of Geopolymer composites-Mechanical properties and rheological characteristics: A review. Constr. Build. Mater. 2019, 220, 547-564. [CrossRef]

26. Si, R.; Guo, S.; Dai, Q.; Wang, J. Atomic-structure, microstructure and mechanical properties of glass powder modified metakaolinbased geopolymer. Constr. Build. Mater. 2020, 254, 119303. [CrossRef]

27. Si, R.; Dai, Q.; Guo, S.; Wang, J. Mechanical property, nanopore structure and drying shrinkage of metakaolin-based geopolymer with waste glass powder. J. Clean. Prod. 2020, 242, 118502. [CrossRef]

28. Zhang, Y.; Xiao, R.; Jiang, X.; Li, W.; Zhu, X.; Huang, B. Effect of particle size and curing temperature on mechanical and microstructural properties of waste glass-slag-based and waste glass-fly ash-based geopolymers. J. Clean. Prod. 2020, $273,122970$. [CrossRef]

29. Vafaei, M.; Allahverdi, A. High strength geopolymer binder based on waste-glass powder. Adv. Powder Technol. 2017, 28 , 215-222. [CrossRef]

30. Idir, R.; Cyr, M.; Pavoine, A. Investigations on the durability of alkali-activated recycled glass. Constr. Build. Mater. 2020, 236, 117477. [CrossRef]

31. Chen, T.-A.; Chen, J.-H.; Huang, J.-S. Effects of activator and aging process on the compressive strengths of alkali-activated glass inorganic binders. Cem. Concr. Compos. 2017, 76, 1-12. [CrossRef]

32. Xiao, R.; Ma, Y.; Jiang, X.; Zhang, M.; Zhang, Y.; Wang, Y.; Huang, B.; He, Q. Strength, microstructure, efflorescence behavior and environmental impacts of waste glass geopolymers cured at ambient temperature. J. Clean. Prod. 2020, 252, 119610. [CrossRef]

33. Toniolo, N.; Rincón, A.; Avadhut, Y.; Hartmann, M.; Bernardo, E.; Boccaccini, A.R. Novel geopolymers incorporating red mud and waste glass cullet. Mater. Lett. 2018, 219, 152-154. [CrossRef]

34. Kastiukas, G.; Zhou, X.; Wan, K.T.; Gomes, J.C. Lightweight Alkali-Activated Material from Mining and Glass Waste by Chemical and Physical Foaming. J. Mater. Civ. Eng. 2019, 31, 04018397. [CrossRef]

35. Burciaga-Díaz, O.; Durón-Sifuentes, M.; Díaz-Guillén, J.; Escalante-García, J. Effect of waste glass incorporation on the properties of geopolymers formulated with low purity metakaolin. Cem. Concr. Compos. 2020, 107, 103492. [CrossRef]

36. Coppola, B.; Palmero, P.; Montanaro, L.; Tulliani, J.-M. Alkali-activation of marble sludge: Influence of curing conditions and waste glass addition. J. Eur. Ceram. Soc. 2020, 40, 3776-3787. [CrossRef]

37. Archez, J.; Texier-Mandoki, N.; Bourbon, X.; Caron, J.; Rossignol, S. Influence of the wollastonite and glass fibers on geopolymer composites workability and mechanical properties. Constr. Build. Mater. 2020, 257, 119511. [CrossRef]

38. Senff, L.; Novais, R.; Carvalheiras, J.; Labrincha, J. Eco-friendly approach to enhance the mechanical performance of geopolymer foams: Using glass fibre waste coming from wind blade production. Constr. Build. Mater. 2020, 239, 117805. [CrossRef]

39. Bai, T.; Liu, B.; Wu, Y.-G.; Huang, W.; Sha, A.; Xia, Z. Mechanical properties of metakaolin-based geopolymer with glass fiber reinforcement and vibration preparation. J. Non-Crystalline Solids 2020, 544, 120173. [CrossRef]

40. Hajimohammadi, A.; Ngo, T.; Kashani, A. Glass waste versus sand as aggregates: The characteristics of the evolving geopolymer binders. J. Clean. Prod. 2018, 193, 593-603. [CrossRef]

41. Khan, N.N.; Sarker, P.K. Effect of waste glass fine aggregate on the strength, durability and high temperature resistance of alkali-activated fly ash and GGBFS blended mortar. Constr. Build. Mater. 2020, 263, 120177. [CrossRef]

42. Lo, K.-W.; Lin, K.-L.; Cheng, T.-W.; Shiu, H.-S. Effect of alkali activation thin film transistor-liquid crystal display waste glass on the mechanical behavior of geopolymers. Constr. Build. Mater. 2018, 162, 724-731. [CrossRef] 
43. Novais, R.M.; Ascensão, G.; Seabra, M.P.; Labrincha, J.A. Waste glass from end-of-life fluorescent lamps as raw material in geopolymers. Waste Manag. 2016, 52, 245-255. [CrossRef] [PubMed]

44. Moncea, A.-M.; Georgescu, M.; Badanoiu, A.; Matei, E.; Stoleriu, S. Alkali activated binders as matrices for the immobilization of glass waste with $\mathrm{Pb}$ content. In Proceedings of the 18th International Conference on Building Materials (IBAUSIL 2012), Weimar, Germany, 12-15 September 2012; Volume 1, p. 9.

45. Moncea, A.M.; Georgescu, M.; Melinescu, A.; Stoleriu, T.; Moncea, A. Hardening processes and hydrates in alkali-activated slag and geopolymer with $\mathrm{Pb}$ content. Rom. J. Mater. 2012, 42, 356-363.

46. Moncea, A.M.; Badanoiu, A.; Georgescu, M.; Stoleriu, S. Cementitious composites with glass waste from recycling of cathode ray tubes. Mater. Struct. 2013, 46, 2135-2144. [CrossRef]

47. Catauro, M.; Lancellotti, I.; Leonelli, C. Addition of WEEE Glass to Metakaolin-Based Geopolymeric Binder: A Cytotoxicity Study. Environments 2017, 4, 89. [CrossRef]

48. Mary, B.O.; Ikpeni, S.E. Metakaolin clay-derived geopolymer for recycling of waste cathode ray tube glass. Afr. J. Pure Appl. Chem. 2018, 12, 42-49. [CrossRef]

49. Long, W.-J.; Li, H.-D.; Ma, H.; Fang, Y.; Xing, F. Green alkali-activated mortar: Sustainable use of discarded cathode-ray tube glass powder as precursor. J. Clean. Prod. 2019, 229, 1082-1092. [CrossRef]

50. Yang, M.; Paudel, S.R.; Asa, E. Comparison of pore structure in alkali activated fly ash geopolymer and ordinary concrete due to alkali-silica reaction using micro-computed tomography. Constr. Build. Mater. 2020, 236, 117524. [CrossRef]

51. Guzmán-Carrillo, H.; Gasca-Tirado, J.; López-Romero, J.; Luis, M.A.-C.; Eric, M.R.-M.; Pineda-Piñón, J.; Pérez-Bueno, J.; FeregrinoMontes, C.; López-Naranjo, E.; Manzano-Ramírez, A. Encapsulation of toxic heavy metals from waste CRT using calcined kaolin base-geopolymer. Mater. Chem. Phys. 2021, 257, 123745. [CrossRef]

52. Opletal, T. Možnosti zpracování odpadního obrazovkového skla (Possibilities of recycling waste screen glass). Master's Thesis, Univerzita Palackého v Olomouci, Př́rodovědecká Fakulta, Katedra Geologie (Palacký University in Olomouc, Faculty of Science, Department of Geology), Olomouc, Turkey, 2013.

53. Opletal, T.; Sulkovsky, P. Scientific Research Abstracts'. In Alkali Activation-a New Way of Recycling CRT Glass; Castellaneta Marina: Taranto, Italy, June 2015; Volume 4, p. 23.

54. Al Bakria, A.M.; Kamarudin, H.; Binhussain, M.; Nizar, I.; Zarina, Y.; Rafiza, A. The Effect of Curing Temperature on Physical and Chemical Properties of Geopolymers. Phys. Procedia 2011, 22, 286-291. [CrossRef]

55. Mo, B.-H.; Zhu, H.; Cui, X.; He, Y.; Gong, S.-Y. Effect of curing temperature on geopolymerization of metakaolin-based geopolymers. Appl. Clay Sci. 2014, 99, 144-148. [CrossRef]

56. Görhan, G.; Aslaner, R.; Şinik, O. The effect of curing on the properties of metakaolin and fly ash-based geopolymer paste. Compos. Part B 2016, 97, 329-335. [CrossRef]

57. Ekaputri, J.J.; Junaedi, S. Wijaya Effect of Curing Temperature and Fiber on Metakaolin-based Geopolymer. Procedia Eng. 2017, 171, 572-583. [CrossRef]

58. EN 196-1. Method of Testing Cement-Part 1: Determination of Strength; European Committee for Standardization: Brussels, Belgium, 1 April 2016.

59. Alonso, S.; Palomo, A. Alkaline activation of metakaolin and calcium hydroxide mixtures: Influence of temperature, activator concentration and solids ratio. Mater. Lett. 2001, 47, 55-62. [CrossRef]

60. Riahi, S.; Nemati, Z.A.; Khodabandeh, A.; Baghshahi, S. The effect of mixing molar ratios and sand particles on microstructure and mechanical properties of metakaolin-based geopolymers. Mater. Chem. Phys. 2020, 240, 122223. [CrossRef]

61. Lancellotti, I.; Catauro, M.; Ponzoni, C.; Bollino, F.; Leonelli, C. Inorganic polymers from alkali activation of metakaolin: Effect of setting and curing on structure. J. Solid State Chem. 2013, 200, 341-348. [CrossRef]

62. Sun, Z.; Vollpracht, A. One year geopolymerisation of sodium silicate activated fly ash and metakaolin geopolymers. Cem. Concr. Compos. 2019, 95, 98-110. [CrossRef]

63. Yuan, J.; He, P.; Jia, D.; Yang, C.; Zhang, Y.; Yan, S.; Yang, Z.; Duan, X.; Wang, S.; Zhou, Y. Effect of curing temperature and $\mathrm{SiO} 2 / \mathrm{K} 2 \mathrm{O}$ molar ratio on the performance of metakaolin-based geopolymers. Ceram. Int. 2016, 42, 16184-16190. [CrossRef]

64. Rovnaník, P. Effect of curing temperature on the development of hard structure of metakaolin-based geopolymer. Constr. Build. Mater. 2010, 24, 1176-1183. [CrossRef]

65. Wang, H.; Li, H.; Yan, F. Synthesis and mechanical properties of metakaolinite-based geopolymer. Colloids Surf. A Physicochem. Eng. Asp. 2005, 268, 1-6. [CrossRef]

66. Steveson, M.; Sagoe-Crentsil, K. Relationships between composition, structure and strength of inorganic polymers. J. Mater. Sci. 2005, 40, 2023-2036. [CrossRef]

67. Yao, X.; Zhang, Z.; Zhu, H.; Chen, Y. Geopolymerization process of alkali-metakaolinite characterized by isothermal calorimetry. Thermochim. Acta 2009, 493, 49-54. [CrossRef] 